\title{
Impacts of environmental factors on arsenate biotransformation and release in Microcystis aeruginosa using Taguchi experimental design
}

\author{
Z.H. Wang ${ }^{1,2}$, Z.X. Luo $^{2}$ \& C.Z. Yan ${ }^{2}$ \\ ${ }^{1}$ College of Chemistry and Environment, Fujian Province Key Laboratory of Modern Analytical Science and \\ Separation Technology, Minnan Normal University, Zhangzhou, China \\ ${ }^{2}$ Key Laboratory of Urban Environment and Health, Institute of Urban Environment, Chinese Academy of Sciences, \\ Xiamen, China
}

\begin{abstract}
We conducted a series of experiments using Taguchi methods to determine optimum conditions for arsenic (As) biotransformation. We found that $\mathrm{N}$ is critical for $M$. aeruginosa $\mathrm{As}(\mathrm{V})$ biotransformation, particularly with regard to As(III) transformation. Also, As accumulation benefited from low P levels when combined with high $\mathrm{N}$ concentrations. Phosphate was second to $\mathrm{As}(\mathrm{V})$ as the primary factor to affect As accumulation. Additionally, we found that the small amounts of As that accumulated under low concentrations of As and high $\mathrm{P}$ were tightly stored in living algal cells and were easily released after cell death. Our results will be helpful for the understanding, practical applications, and overall control of the key environmental factors, particularly those associated with algal bioremediation for As-polluted water.
\end{abstract}

\section{INTRODUCTION}

Algae are widely distributed in aquatic ecosystems and play an important role in arsenic (As) bioaccumulation and biogeochemical cycling (Duncan et al., 2015; Yan et al., 2016). Microcystis aeruginosa is generally tolerant to $\mathrm{As}(\mathrm{V})$ and exhibits a stronger As bioaccumulation capacity compared to other freshwater algae (Wang et al., 2017). Many abiotic factors affect the metabolic functions of alga contaminated by As, such as As levels, hydrogen ion levels $(\mathrm{pH})$, and key nutrient concentrations of nitrogen $(\mathrm{N})$ and phosphorus $(\mathrm{P})$ in culture media. To date, very limited information is available on how and to what extent environmental factors influence arsenic (As) biotransformation and release in freshwater algae. To further understand environmental factors that impact $\mathrm{As}(\mathrm{V})$ uptake, we investigated As biotransformation and release in $M$. aeruginosa, aspects of its growth, intracellular As accumulation in algae cells, and release after algae death. Taguchi methods under their relevant statistical assumptions were applied to determine optimum environmental conditions.

\section{METHODS}

\subsection{Experimental design}

Three different levels in combination with actual aquatic conditions of each environmental factor were considered (Table 1). Accordingly, we chose an L9 $\left(3^{4}\right)$ orthogonal array, and we obtained experimental conditions (Table 2 ) by combining Table 1 and the L9 $\left(3^{4}\right)$ orthogonal array. We used experimental data to determine optimal experimental conditions and evaluate experimental results, which we assessed using
Table 1. Environmental factors of the orthogonal test.

\begin{tabular}{lllrr}
\hline Factor & $\begin{array}{l}\mathrm{NO}_{3}^{-}-\mathrm{N} \\
\left(\mathrm{mg} \mathrm{L}^{-1}\right)\end{array}$ & $\begin{array}{l}\mathrm{PO}_{4}^{3-}-\mathrm{P} \\
\left(\mathrm{mg} \mathrm{L}^{-1}\right)\end{array}$ & $\mathrm{pH}$ & $\begin{array}{r}A s(\mathrm{~V}) \\
(\mu \mathrm{M})\end{array}$ \\
\hline Level 1 & 2 & 0.02 & 6 & 0.1 \\
Level 2 & 4 & 0.20 & 8 & 1.0 \\
Level 3 & 10 & 1.00 & 10 & 10.0 \\
\hline
\end{tabular}

Table 2. Experimental L $9\left(3^{4}\right)$ orthogonal array.

\begin{tabular}{|c|c|c|c|c|}
\hline \multirow[b]{2}{*}{ Treatment } & \multicolumn{4}{|c|}{ Parameters } \\
\hline & $\begin{array}{l}\mathrm{NO}_{3}^{-}-\mathrm{N} \\
\left(\mathrm{mg} \mathrm{L}^{-1}\right)\end{array}$ & $\begin{array}{l}\mathrm{PO}_{4}^{3-}-\mathrm{P} \\
\left(\mathrm{mg} \mathrm{L}^{-1}\right)\end{array}$ & $\mathrm{pH}$ & $\begin{array}{l}A s(\mathrm{~V}) \\
\mu \mathrm{M}\end{array}$ \\
\hline E1 & 2 & 0.02 & 6 & 0.1 \\
\hline E2 & 2 & 0.2 & 8 & 1.0 \\
\hline E3 & 2 & 1.0 & 10 & 10 \\
\hline E4 & 4 & 0.02 & 8 & 10 \\
\hline E5 & 4 & 0.2 & 10 & 0.1 \\
\hline E6 & 4 & 1.0 & 6 & 1.0 \\
\hline E7 & 10 & 0.02 & 10 & 1.0 \\
\hline E8 & 10 & 0.2 & 6 & 10 \\
\hline E9 & 10 & 1.0 & 8 & 0.1 \\
\hline
\end{tabular}

analysis of variance (ANOVA) and the signal-to-noise $(\mathrm{S} / \mathrm{N})$ ratio with biggest characteristics.

\subsection{Batch culture preparation}

The $M$. aeruginosa cultures that we used were incubated in BG-11 without adding additional $\mathrm{N}$ and $\mathrm{P}$ for $48 \mathrm{~h}$ after exponential phases of algal suspension growth were centrifuged and washed twice in sterile Milli-Q water. We separated the above cultures into nine equal parts, which were once again centrifuged and washed in sterile Milli-Q water. They were aseptically transferred to nine sterile $1 \mathrm{~L}$ Erlenmeyer flasks 


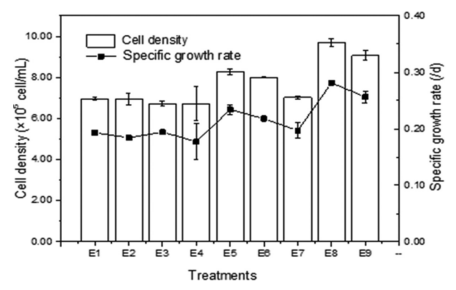

Figure 1. Cell density and the specific growth rate of M. aeruginosa under different treatments.

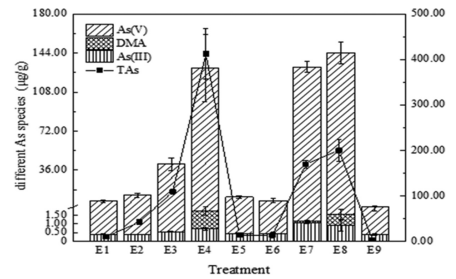

Figure 2. Intracellular total As and different As species concentrations in $M$. aeruginosa under different treatments.

( 2 replicates per treatment), containing $250 \mathrm{~mL}$ of different autoclaved sterilized modified BG-11 media, according to Table 2 . After cultured batch treatments in an illuminated incubator shaker for $96 \mathrm{~h}$, We then harvested approximately $20 \mathrm{~mL}$ of the algae via centrifugation at $4500 \times \mathrm{g}$ for $10 \mathrm{~min}$. Media was also frozen to determine total As (TAs) and the specific As species.

\section{RESULTS AND DISCUSSION}

\subsection{Algae growth}

The final cell density and specific growth rate obtained at the conclusion of the $96 \mathrm{~h}$ experiment were plotted in Figure 1, which further indicated variation in parameter level combinations. $\mathrm{NO}_{3}^{-}-\mathrm{N}$ was found to be the most influential among the four factors on algal growth while $\mathrm{PO}_{4}^{3-}-\mathrm{P}$ was the second most influential factor.

\subsection{Intracellular arsenic bioaccumulation}

We ascertained TAs content and As species in algal cells after $96 \mathrm{~h}$ in culture media (Fig. 2). High As bioaccumulation and its facilitation by $\mathrm{N}$ in media indicated that $\mathrm{N}$ could affect algae bioremediation in As polluted water. M. aeruginosa could accumulate greater $\mathrm{As}(\mathrm{V})$ in cells under high $\mathrm{As}(\mathrm{V})$ ambient concentrations, coexisting with low $\mathrm{P}$ and high $\mathrm{N}$ concentrations. Being key factors affecting intracellular TAs and $\mathrm{As}(\mathrm{V})$ accumulation, their similarity in chemical properties between $P$ and As determined that $P$ was second to As in rank and order.

\subsection{Arsenic biotransformation in media}

With the exception of $A s(\mathrm{~V})$, we detected $A s$ biotransformation and DMA in media after $96 \mathrm{~h}$ in algal culture (Fig. 3). Although high $A s(\mathrm{III})$ and DMA concentrations in media were primarily caused by the high $A s(\mathrm{~V})$ levels, its reduction to $A s(\mathrm{III})$ in media was

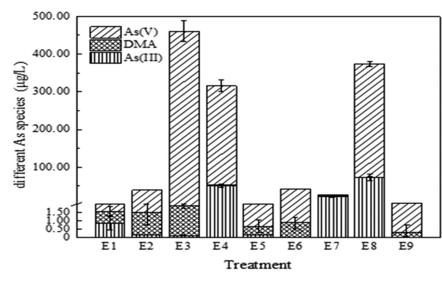

Figure 3. Different As species concentrations in culture media under different treatments.

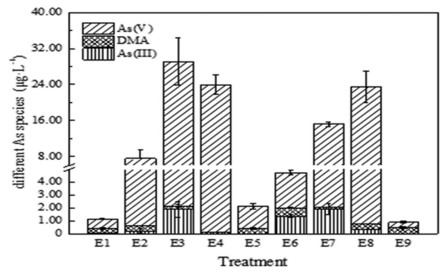

Figure 4. Different As species concentrations in culture media from dead algae cells under different treatments.

inclined to occur in high $N$ and low $P$ concentrations under slightly acidic environments. As the principal factor, $N$ exhibited a significantly positive effect on $A s$ (III) concentrations in culture media after $A s$ was introduced.

\subsection{Arsenic release from dead algae}

This study found that As was rapidly released from dead algal cells. Figure 4 shows that approximately $58 \%$ to $93 \%$ As was released after $8 \mathrm{~h}$ resuspension. The high As uptake in algae with increasing initial concentrations of As $(\mathrm{V})$ could result in high As efflux from dead cells. The $\mathrm{pH}$ factor yielded principal effects on As(III) and methylated As (OAs) efflux.

\section{ACKNOWLEDGMENTS}

This study was jointly supported by the National Nature Science Foundation of China (project nos. 41401552, 41271484 and 21277136) and the Nature Science Foundation of Fujian Province (2016J01691).

\section{REFERENCES}

Duncan, E.G., Maher, W.A. \& Foster, S.D. 2015. Contribution of arsenic species in unicellular algae to the cycling of arsenic in marine ecosystems. Environ. Sci. Technol. 49(1): 33-50.

Wang, Z. H., Luo, Z. X., Yan, C. Z. \& Xing, B. S. 2017. Impacts of environmental factors on arsenate biotransformation and release in Microcystis aeruginosa using the Taguchi experimental design approach. Water Res. 118: $167-176$.

Yan, C.Z., Che, F.F., Zeng, L.Q., Wang, Z.S., Du, M.M., Wei, Q.S., Wang, Z.H., Wang, D.P. \& Zhen, Z. 2016. Spatial and seasonal changes of arsenic species in Lake Taihu in relation to eutrophication. Sci. Total Environ. 563-564: 496-505. 